Wilfrid Laurier University

Scholars Commons @ Laurier

1977

\title{
Preliminary Characterization of Peroxidase Isozymes Isolated from Two Flax Genotrophs
}

\author{
Mary Ann Fieldes \\ Wilfrid Laurier University, mfieldes@wlu.ca
}

C.L. Deal

McGill University

H. Tyson

McGill University

Follow this and additional works at: https://scholars.wlu.ca/biol_faculty

\section{Recommended Citation}

Fieldes, Mary Ann; Deal, C.L.; and Tyson, H., "Preliminary Characterization of Peroxidase Isozymes Isolated from Two Flax Genotrophs" (1977). Biology Faculty Publications. 18.

https://scholars.wlu.ca/biol_faculty/18

This Article is brought to you for free and open access by the Biology at Scholars Commons @ Laurier. It has been accepted for inclusion in Biology Faculty Publications by an authorized administrator of Scholars Commons @ Laurier. For more information, please contact scholarscommons@wlu.ca. 


\title{
Preliminary characterization of peroxidase isozymes isolated from two flax genotrophs
}

\author{
M. A. Fieldes, C. L. Deal, and H. Tyson \\ Department of Biology, McGill University, Montreal, Que., Canada \\ Received July 29, 1976
}

\begin{abstract}
Fieldes, M. A., C. L. DeAl, and H. Tyson. 1977. Preliminary characterization of peroxidase isozymes isolated from two flax genotrophs. Can. J. Bot. 55: 1465-1473.

Four peroxidase (EC 1.11.1.7) isozymes were isolated from each of two flax genotrophs. All four isozymes were glycoproteins and all exhibited indoleacetic acid (IAA) oxidase activity. The percentage purity of two of the isozymes was very high; these isozymes differed in percentage carbohydrate and in peroxidase and IAA oxidase specific activities. Three of the isozymes displayed molecular weight values of about 43000 ; for the fourth, molecular weight was considerably higher. Corresponding isozymes from the genotrophs and from two other flax genotypes displayed molecular weight differences which corresponded to electrophoretic relative mobility differences. Enzyme yield per unit fresh weight was higher for one genotroph than the other, and the balance between peroxidase activity and IAA oxidase activity between the genotrophs was different.
\end{abstract}

\section{Introduction}

Environmental induction of heritable changes in the inbreeding species of flax, Linum usitatissimum, has been described in detail by Durrant $(1962 a, 1962 b, 1971)$. The contrasting genotrophs $\mathrm{L}$ (large) and $\mathrm{S}$ (small) were induced in the genotype Stormont Cirrus by one generation's growth in high levels of either nitrogen, phosphorus, and potassium (NPK, induction of L), or nitrogen and potassium (NK, induction of S). Successive progeny generations resulting from complete selfing in each previous generation were grown in uniform environmental conditions. Random sampling of the seed of L or of S in any one generation supplied the plants of $\mathrm{L}$ or of $\mathrm{S}$ in the next. The progenies of the original two fertilizer treatments, that is, the genotrophs $\mathrm{L}$ and $\mathrm{S}$, behaved as distinct genotypes.

Anionic peroxidase (EC 1.11.1.7) isozymes from L and S (Fieldes and Tyson 1972, 1973a, $1973 b$ ) showed similar overall patterns, with one fast-moving band of high activity and three slower moving bands of lesser activity. The essential differences between $\mathrm{L}$ and $\mathrm{S}$ anionic isozymes were the lower relative mobilities $(R m \mathrm{~s})$ and higher activities of each of the $\mathrm{S}$ isozymes compared with the corresponding $\mathrm{L}$ isozymes. These environmentally induced heritable shifts in $R m$ between $\mathrm{L}$ and $\mathrm{S}$ indicated modifications of the glycoprotein molecular structure of peroxidase. Isolation and purification techniques for flax peroxidase isozymes from two genotypes have been described (Fieldes et al. 1976); the same techniques successfully yielded samples of the four isozymes from the $\mathrm{L}$ and $\mathrm{S}$ genotrophs. Some preliminary characteristics of the genotrophs' isozymes could thus be evaluated and compared, as a step towards finding what alterations in peroxidase molecular structure resulted from the original environmental treatments which induced the heritable changes in Stormont Cirrus.

Peroxidase was initially chosen for study, in relation to biochemical changes induced in $\mathrm{L}$ and $\mathrm{S}$, because of its involvement in the oxidase system controlling indole acetic acid (IAA) level within plant tissues (Galston et al. 1953). Differences in the degree of basal branching between $\mathrm{L}$ and $\mathrm{S}$ suggested variation in IAA level as a possible mechanism. Such branching differences also occur between the Royal (R) and Mandarin (M) genotypes; $R$ and $L$ have more basal branching than $M$ and $S$ respectively, although the peroxidase activities and $R m s$ of corresponding isozymes do not follow the expected same relationship; $R$ resembles $S$, and $M$ resembles $L$. While peroxidase may have additional roles within plant tissues (Hess 1968) the activities of individual $\mathrm{L}$ and $\mathrm{S}$ isozymes as IAA oxidases have also been examined in the work reported here.

\section{Materials and Methods}

Plant Extracts, Isozyme Isolation, and Purification

Genotypes

The growing conditions for $\mathrm{R}$ and $\mathrm{M}$ plants and the isolation and purification of their peroxidase isozymes have been detailed (Fieldes et al 1976). Plants were grown in a controlled environment chamber, and harvested 37 
days after sowing. Main stem tissue was homogenized, yielding a bulk extract for each genotype which was strained through nylon mesh and centrifuged. Duplicate $500-\mathrm{ml}$ aliquots of each of the two resulting supernatants were treated with ammonium sulphate, and the $35-90 \%$ saturation precipitates used for isolation of isozymes 1,2 , 3 , and 4 (in order of increasing $R m$ ). Using various modifications of Shannon et al.'s (1966) techniques with cation and anion exchange chromatography, as well as gel filtration chromatography, four isozymes were isolated from each of the four original 500 -ml aliquots, yielding 16 peroxidase samples from $R$ and $M$. Some characteristics have already been reported for these 16 samples (Fieldes et al. 1976).

Genotrophs

Stormont Cirrus plants were grown in high NPK or high NK for one generation to induce the contrasting $L$ and $\mathrm{S}$ genotrophs, and were subsequently maintained over 16 progeny generations in uniform environmental conditions, which was the point at which they were sampled in this study. The induction techniques have been described by Durrant (1962a, 1971), who provided the advanced generation genotroph seed.

Plants of both genotrophs were grown in a randomized block design in a controlled environment chamber, with 500 plants of $\mathrm{L}$ and of $\mathrm{S}$ in each of two replicates; plants were harvested 43 days after sowing. Growing conditions, extraction, isolation, and purification steps were exactly as detailed for the genotypes (Fieldes et al. 1976), except that the bulk extracts were prepared from each replicate of each genotroph, so that extraction differences were confounded with replicate differences. The four bulk extracts were each about $2 \ell$, varying slightly with the weight of stem tissue homogenzied in each bulk. Use of the entire volume of each supernatant increased the isozyme yields for genotrophs compared with genotypes, and also improved percentage recovery at each stage in the isolation and purification procedure; 16 peroxidase samples were obtained.

\section{Protein Content}

Two estimates were made of the total protein content in the peroxidase samples, using Lowry et al.'s (1951) method as well as Waddell's (1956) method. A bovine serum albumin standard curve was used for both methods, and protein content was expressed as micrograms per millilitre.

\section{Carbohydrate Content}

The borosulphuric acid-tryptophan (B-T) assay method developed by Badin et al. (1953) was used to estimate total carbohydrate content in the peroxidase samples. A mannose standard curve was used, and carbohydrate content was expressed as micrograms per millilitre.

\section{Peroxidase Activity}

The guaiacol - hydrogen peroxide method developed by Maehly and Chance (1954) was used, as detailed previously (Hart et al. 1971). Activity was expressed as the increased in optical density (OD) per minute per millilitre $\left(\Delta \mathrm{OD}_{470} \mathrm{~min}^{-1} \mathrm{ml}^{-1}\right)$.

\section{IAA Oxidase Activity}

Darbyshire's (1973) technique, involving (a) reaction of the enzyme sample with a known amount of IAA and (b) assay of IAA remaining unoxidized after a given time, was used with modifications. Cofactor, IAA, and enzyme concentrations, as well as reaction times for steps $(a)$ and (b) were adjusted to prevent complete IAA oxidation, and to measure IAA over the linear range of the Salkowski test (Gordon and Weber 1951). The starting reaction mixture contained $0.1 \mathrm{mM} \mathrm{MnCl}_{2}, 0.05 \mathrm{mM} 2,4$-dichlorophenol, $0.1 \mathrm{M}$ acetate buffer (pH 5.4), and enzyme sample (20-50 $\mu$ g protein). The starting reaction mixture for standards omitted enzyme. After adding $0.5 \mathrm{ml}$ of a 150 $\mu \mathrm{g} / \mathrm{ml}$ IAA solution to $2.0 \mathrm{ml}$ of starting mixture, unoxidized IAA was assayed 30 min later by adding $3.0 \mathrm{ml}$ of modified Salkowski reagent. After a further $25 \mathrm{~min}$ the $\mathrm{OD}_{530}$ values were recorded. IAA oxidase activity was thus expressed in terms of the amount of IAA oxidized under the standard conditions, that is $\triangle O D_{530} \mathrm{~min}^{-1}$ $\mathrm{ml}^{-1}$.

\section{Acrylamide Gel Electrophoresis}

A tris(hydroxymethyl)aminomethane- $\mathrm{HCl}$ (Tris-HCl) gel buffer ( $\mathrm{pH} 8.9), 10 \%$ polyacrylamide, and a Tris-glycine ( $\mathrm{pH} 8.3$ ) electrode buffer system were used; the technique and equipment have been detailed (Hart et al. 1971). Gels were stained for protein, carbohydrate, or peroxidase activity. Two gel tracks of each of the 16 genotroph peroxidase isozyme samples were run for each stain. OD scans of the gels were used for the $R m$ and OD peak area measurements, and the mean values per two gel tracks obtained. Mean areas were expressed initially as square inches $\left(1\right.$ in. $\left.^{2}=645 \mathrm{~mm}^{2}\right)$ per $0.05 \mathrm{ml}$ sample (area $0.05 \mathrm{ml}^{-1}$ ).

\section{Protein Staining in Electrophoresis Gels}

Weber and Osborn's (1969) technique using Coomassie blue was modified; the staining solution contained $1 \%$ Coomassie blue, $25 \%$ isopropanol, and $10 \%$ acetic acid. Gels were stained for $20 \mathrm{~min}$, destained for $24 \mathrm{~h}$ in $15 \%$ methanol and $7.5 \%$ acetic acid using sponge strips to increase the destaining rate, and scanned. $\mathrm{OD}_{560}$ peak areas (area per unit volume) were converted to micrograms per millilitre protein estimates using an ovalbumin standard curve.

\section{Carbohydrate Staining in Electrophoresis Gels}

Zacharius and Zell's (1969) modification of the periodic acid - Schiff's (PAS) technique was used: gels were fixed for $20 \mathrm{~min}$ in $12.5 \%$ trichloracetic acid, washed with water, immersed in $5 \%$ sodium metaperiodate in $3 \%$ acetic acid for $30 \mathrm{~min}$, washed, and stained for $30 \mathrm{~min}$ in fuchsin-sulphite stain in the dark. They were finally destained in $0.5 \%$ potassium metabisulphite and scanned; $\mathrm{OD}_{537}$ peak areas were converted to micrograms per millilitre carbohydrate estimates using an ovalbumin standard curve.

\section{Peroxidase Staining in Electrophoresis Gels}

The guaiacol - hydrogen peroxide staining system detailed by Hart et al. (1971) was used; gels were scanned at $295 \mathrm{~nm}$.

\section{Molecular Weight Estimations by Gel Filtrations}

The $1.67 \times 27 \mathrm{~cm}$ column was Sephadex G-100, equilibrated in $0.005 M$ Tris buffer, $\mathrm{pH} 8.4$; it was calibrated with ribonuclease A (EC 3.1.4.22), chymotrypsinogen A, ovalbumin, and bovine serum albumin monomer as protein standards, and used for molecular weight determinations of all 32 peroxidase samples. The column was run at room temperature; positions of Blue Dextran markers 
and standards in elution fractions were found by scanning at 625 and $230 \mathrm{~nm}$, respectively. Peroxidase positions in elution fractions were located by peroxidase assay. The linear regression of $K_{\mathrm{av}}$ values (partition coefficients) on $\log$ molecular weight for the standards was highly significant; molecular weight values for the peroxidase isozymes were derived from it.

Molecular Weight Estimations by Sodium Dodecyl Sulfate (SDS) Gel Electrophoresis

The electrophoresis system described above was modified by including $1 \%$ SDS in the gel and electrode buffers, and omitting the wetting agent from the gel buffer. Laemmli (1970) has described the use of a similar system. Ten percent polyacrylamide gels were used (Segrest $e t$ al. 1971). The peroxidase samples from the two genotrophs were examined in two tanks, with replicate and tank differences confounded; four protein standards were used to calibrate the tanks, and standards and samples in a tank were run as duplicate gel tracks. Samples were prepared according to method 1 of Weber et al. (1972), and tracks were stained with the modified Coomassie blue system described above. Staining intensity was low compared with non-SDS gels; isozyme 3 (lowest protein content) was clearly visible, but not resolved by scanning. Rms were measured directly from the gels for all four isozymes; linear regressions of $R m$ on $\log$ molecular weight for the four standards within both tanks were highiy significant, but their slopes differed significantly (replicate $1: b=$ $0.92 \pm 0.012$; replicate $2: b=0.83 \pm 0.022$ ). The molecular weight estimates for the samples were, therefore, obtained from the regression appropriate to the tank.

\section{Adjustment of Data and Statistical Analysis}

All assay data were adjusted and expressed as yield ( $\mu \mathrm{g}$ or units activity) per $500 \mathrm{ml}$ of starting volume. The data are given in all tables as averages, over replicates.

Genotroph and genotype data were analyzed separately. Orthogonal comparisons (see results tables) among the eight isozyme-genotroph combinations examined differences between isozymes and between genotrophs, and the isozyme-genotroph interactions. The error used was the interaction between replicates and these eight combinations. Resultant analyses of variance are summarized as $F$ values. Percentage carbohydrate data were transformed to arc sine values before analysis. In analyses of covariance (Wishart 1950), for example in relating IAA oxidase activity to peroxidase activity, the error used was the within genotroph and isozyme combinations component. This supplied the correlation coefficient which indicated the significance and direction of the underlying relationship between the two variables when all other possible factors had been removed.

\section{Results}

\section{Genotroph Isozyme Purity}

Electrophoresis gels of the genotroph samples were stained for protein (Coomassie blue), carbohydrate (PAS), and peroxidase activity, and examined for the purity of each of the isolated isozymes. Contaminants were classified by their $R m s$ from gels stained for protein, and the percentage of each contaminant estimated in terms of protein content. Total protein content of genotroph samples and the protein content and estimated purity of each isozyme are shown in Table 1. Also shown are the $R m s$ of the isozymes and those of the contaminant bands and the percentage impurity represented by each contaminant. All contaminants were glycoproteins with peroxidase activity, except for one impurity in S isozyme 2 and one in S isozyme 4.

Isozyme 3 , when stained for protein, appeared visually to be two bands with virtually identical $R m s$; the gel scans did not distinguish these. No indication of such extremely close double banding occurred in any of the other three isozymes either visually or in scans.

Analyses of $R m$ showed significant differences between corresponding isozymes of $\mathrm{L}$ and $\mathrm{S}$, confirming the same results obtained before isozyme isolation (Fieldes and Tyson 1973a, 1973b).

\section{Protein and Carbohydrate Yields}

Total protein content in each genotroph sample was determined by the Lowry and Waddell methods, and from OD peak areas of the isozyme bands on scans of gels stained with Coomassie blue. Total protein yields (milligrams per 500 millilitres) are shown for $\mathrm{L}$ and $\mathrm{S}$ in Table 2. There was a significant overall protein yield difference between the genotrophs; $\mathrm{S}$ was higher than L. No protein estimates for isozyme 3 could be obtained by the Waddell method; by the other two methods, protein yield for isozyme 3 was significantly lower than the mean yield of the other three isozymes. Although isozymes 1 and 2, averaged over genotrophs, had similar protein yields whichever protein assay method was used, their protein yields relative to that of isozyme 4 varied depending on the particular assay used and also on the genotroph. The Coomassie gel stain showed a significant increase of isozyme 4 over the mean of 1 and 2, which was apparently not detected by the other two assays. Further, this increase was significantly larger for $S$ than for $L$.

The relatively different protein values obtained for genotrophs and isozymes for the Lowry compared with the Waddell assays were reflected in a covariance analysis of the data supplied by the two methods for isozymes 1, 2, and 4. Lowry data showed isozyme 4 with a higher protein yield than the mean of isozymes 1 and 2 , whereas the opposite occurred in the Waddell data. The respective correlation for this comparison 
TABLE 1. Percentage purity of isolated isozymes and $R m$ s and percentages of contaminants from protein-stained electrophoresis gels

\begin{tabular}{|c|c|c|c|c|c|c|c|}
\hline \multirow[b]{2}{*}{ Isozyme } & \multirow[b]{2}{*}{ Genotroph } & \multirow{2}{*}{$\begin{array}{l}\text { Total } \\
\text { protein, } \\
\mu \mathrm{g} / 500 \\
\mathrm{ml}\end{array}$} & \multicolumn{3}{|c|}{ Protein in isozyme band } & \multicolumn{2}{|c|}{ Contaminant bands } \\
\hline & & & $R m$ & $\mu \mathrm{g} / 500 \mathrm{ml}$ & $\%$ purity & $R m$ & $\%$ \\
\hline \multirow[t]{2}{*}{1} & $\mathrm{~L}$ & 91.8 & 0.080 & 91.8 & 100.0 & - & - \\
\hline & $\mathrm{S}$ & 186.3 & 0.072 & 186.3 & 100.0 & - & - \\
\hline \multirow[t]{2}{*}{2} & $\mathrm{~L}$ & 53.7 & 0.196 & 37.1 & 69.8 & $\begin{array}{l}0.315 \\
0.385\end{array}$ & $\begin{array}{r}24.0 \\
6.3\end{array}$ \\
\hline & $S$ & 249.4 & 0.162 & 148.2 & 67.6 & $\begin{array}{l}0.218^{\circ} \\
0.276 \\
0.318\end{array}$ & $\begin{array}{r}26.9 \\
2.5 \\
3.0\end{array}$ \\
\hline \multirow[t]{2}{*}{3} & $\mathrm{~L}$ & 15.2 & 0.226 & 12.3 & 82.8 & 0.145 & 17.2 \\
\hline & $\mathrm{S}$ & 26.3 & 0.207 & 20.3 & 77.1 & 0.143 & 33.0 \\
\hline \multirow[t]{4}{*}{4} & $\mathrm{~L}$ & 303.1 & 0.393 & 294.3 & 97.7 & 0.210 & 2.4 \\
\hline & $\bar{S}$ & 726.0 & 0.372 & 673.2 & 92.7 & 0.143 & 0.9 \\
\hline & & & & & & 0.214 & 2.8 \\
\hline & & & & & & $0.539^{b}$ & 3.6 \\
\hline
\end{tabular}

${ }^{a}$ Based on Coomassie assay method.

DNon-glycoprotein contaminants.

TABLE 2. Mean protein content and carbohydrate content for the four isozymes of both genotrophs

\begin{tabular}{|c|c|c|c|c|c|c|c|}
\hline & \multicolumn{3}{|c|}{ Protein yield, $\mathrm{mg} / 500 \mathrm{ml}$} & \multicolumn{2}{|c|}{$\begin{array}{c}\text { Carbohydrate yield, } \\
\mathrm{mg} / 500 \mathrm{ml}\end{array}$} & \multicolumn{2}{|c|}{ \% carbohydrate ${ }^{a}$} \\
\hline & Lowry & Waddell & Coomassie & $\mathrm{B}-\mathrm{T}$ & PAS & $\mathrm{B}-\mathrm{T}$ & PAS \\
\hline \multicolumn{8}{|l|}{ Genotroph S } \\
\hline Isozyme 1 & 1.331 & 0.853 & 0.186 & 0.184 & 0.483 & 12.1 & 27.0 \\
\hline Isozyme 2 & 1.202 & 0.756 & 0.249 & 0.098 & 0.190 & 7.6 & 13.5 \\
\hline Isozyme 3 & 0.112 & - & 0.026 & 0.020 & 0.005 & 15.2 & 3.9 \\
\hline Isozyme 4 & 1.362 & 0.652 & 0.726 & 0.083 & 0.212 & 5.6 & 13.4 \\
\hline Mean & 1.000 & 0.754 & 0.297 & 0.096 & 0.222 & 10.1 & 14.5 \\
\hline \multicolumn{8}{|l|}{ Genotroph L } \\
\hline Isozyme 1 & 0.704 & 0.476 & 0.092 & 0.106 & 0.194 & 13.2 & 21.2 \\
\hline Isozyme 2 & 0.358 & 0.170 & 0.054 & 0.038 & 0.061 & 9.5 & 14.3 \\
\hline Isozyme 3 & 0.092 & - & 0.015 & 0.022 & 0.009 & 18.9 & 8.9 \\
\hline Isozyme 4 & 0.930 & 0.463 & 0.303 & 0.043 & 0.144 & 4.8 & 13.7 \\
\hline \multirow[t]{2}{*}{ Mean } & 0.521 & 0.370 & 0.116 & 0.052 & 0.102 & 11.6 & 14.5 \\
\hline & & & $F$ values $^{b}$ & & & & \\
\hline Comparison of $\mathrm{L}$ vs. $\mathrm{S}$ & $16.6^{* *}$ & $16.2^{* *}$ & $20.7^{* * *}$ & $12.3^{* *}$ & $11.3^{*}$ & $<1.0$ & $<1.0$ \\
\hline Isozyme 1 vs. 2 & 2.0 & 3.0 & $<1.0$ & $18.7^{* * *}$ & $17.7^{* *}$ & $10.4^{*}$ & $5.9^{*}$ \\
\hline Isozyme 4 vs. mean $1+2$ & 2.9 & $<1.0$ & $57.4^{* *}$ & $7.7^{*}$ & 1.5 & $31.7^{* *}$ & 2.2 \\
\hline \multicolumn{8}{|l|}{ Isozyme 3 vs. mean } \\
\hline $1+2+4$ & $41.7^{* *}$ & - & $29 . L^{* *}$ & $23.9^{* *}$ & $25.6^{* *}$ & $58.0^{* *}$ & $15.8^{* *}$ \\
\hline
\end{tabular}

amongst isozymes in the covariance analysis was negative; this was also found in a comparable analysis of genotype data (Fieldes et al. 1976). The correlation in the error line was, however, positive and significant $\left(r_{s}=+0.917\right)$ suggesting that once the effects of the main factors were removed, there was basic agreement between the Lowry and Waddell assay results. A similar covariance comparison of the Lowry and
Coomassie genotroph data also showed basic agreement after main factors were removed (error line correlation, $r_{7}=+0.724$ ). The protein yield estimates obtained by the Coomassie method were considerably lower than those obtained by the other two methods.

Carbohydrate (CHO) yields from the B-T method (in terms of mannose equivalents), and from the OD peak areas of gel scans after PAS 
staining, are shown in Table 2. There was a significant overall $\mathrm{CHO}$ yield difference between the genotrophs; S was higher than L. Isozyme 1 had the highest $\mathrm{CHO}$ yield and isozyme 3 the lowest. The relationship between the $\mathrm{CHO}$ yield for isozyme 4 and the mean for 1 and 2 varied depending on the assay method used. Comparison of the $\mathrm{CHO}$ yields obtained suggested basic agreement between the two assay methods (covariance analysis correlation coefficient, $r_{7}=$ $+0.821)$.

\section{Percentage Carbohydrate}

Carbohydrate as a percentage of total yield (CHO plus protein) was calculated by using Lowry protein data and both sets of $\mathrm{CHO}$ data. The \% CHO values are shown in Table 2. Analyses of percentage $\mathrm{CHO}$ data both showed significantly higher percentage $\mathrm{CHO}$ for isozyme I compared with 2 . The percentage $\mathrm{CHO}$ for isozyme 4 was significantly lower than the mean for 1 and 2 in the B-T percentage data; this stemmed mainly from the high percentage $\mathrm{CHO}$ value for isozyme 1 relative to that for 4 . This relationship between isozymes 1 and 4 occurred regardless of the $\mathrm{CHO}$ assay used or the method used for protein estimation. No significant genotroph differences were detected.

\section{Peroxidase and IAA Oxidase Activities}

Enzyme activities per $500 \mathrm{ml}$ initial extract (enzyme yield) and specific activities per milligram protein (based on Lowry) are shown for genotypes and genotrophs in Table 3. Yield and specific activity of isozyme 4 were significantly higher than the mean of 1 and 2 in all cases (this isozyme comparison was also significant in the analysis of variance of specific activity data based on Coomassie estimates of protein yield). Significant interactions resulted in some cases from the larger $\mathrm{L}-\mathrm{S}$ or $\mathrm{R}-\mathrm{M}$ difference for 4 compared with that for the mean of the other three isozymes.

Although the overall difference in peroxidase yield between the genotypes was significant, that between the genotrophs was not. Nevertheless, the genotroph difference here agreed with previous peroxidase data (Fieldes and Tyson 1973a, 1973b). There were no significant differences between genotrophs or genotypes for IAA oxidase yield or for either specific activities. As yields, however, peroxidase and IAA oxidase were higher for $S$ and $R$ than for $L$ and $M$ respectively, while as specific activities, this clear partition was absent.
The apparent positive correlation between the dual functions of each variant of this enzyme molecule indicated that covariance analysis could be used to compare the balance of the two enzyme functions between genotrophs and between genotypes. The enzyme functions as yields and as specific activities were therefore compared by covariance analyses, conducted separately for genotrophs and genotypes. The four covariance analyses are summarized in Table 4 . The error line (pooled) correlations were all positive and significant, indicating basic correlation between the two enzyme functions. These correlations were therefore partitioned to examine the basic correlation between the dual functions within each genotroph or genotype.

For enzyme yield the correlation coefficients for both genotrophs and both genotypes were positive and significant; for each the corresponding regression slopes for IAA oxidase yield on peroxidase yield are also given in Table 4. For genotrophs, there was no significant difference in the basic rate of change in IAA oxidase yield per unit change in peroxidase yield. Adjusted to a mean peroxidase value, IAA oxidase yield was significantly higher for $\mathrm{S}$ than for $\mathrm{L}$ (Table 4). Thus, despite the basic correlation between the dual enzyme functions, the balance between these functions was different between $\mathrm{L}$ and $\mathrm{S}$. For genotypes, the rate of change in IAA oxidase yield per unit change in peroxidase yield was significantly faster for $\mathrm{R}$ than for $\mathrm{M}$; the interdependence of the dual functions therefore differed between the genotypes, and the genotypes could not be tested for differences between adjusted IAA oxidase means.

For specific activity, the correlation coefficients for $\mathrm{L}$ and $\mathrm{R}$ were positive and significant and for $S$ and $M$ were negative (not significant for S). The basic rate of change in IAA oxidase specific activity per unit change in peroxidase specific activity was therefore obviously different between genotrophs and between genotypes.

\section{Molecular Weight Estimates}

The molecular weight values obtained for the isozymes of the genotrophs and the genotypes, averaged over replicates, are shown in Table 5.

In an analysis of variance on all the gel filtration data, genotrophs and genotypes together, the genotroph and genotype differences were highly significant and the mean molecular weight for genotrophs was significantly higher than that 
CAN. J. BOT. VOL. 55, 1977

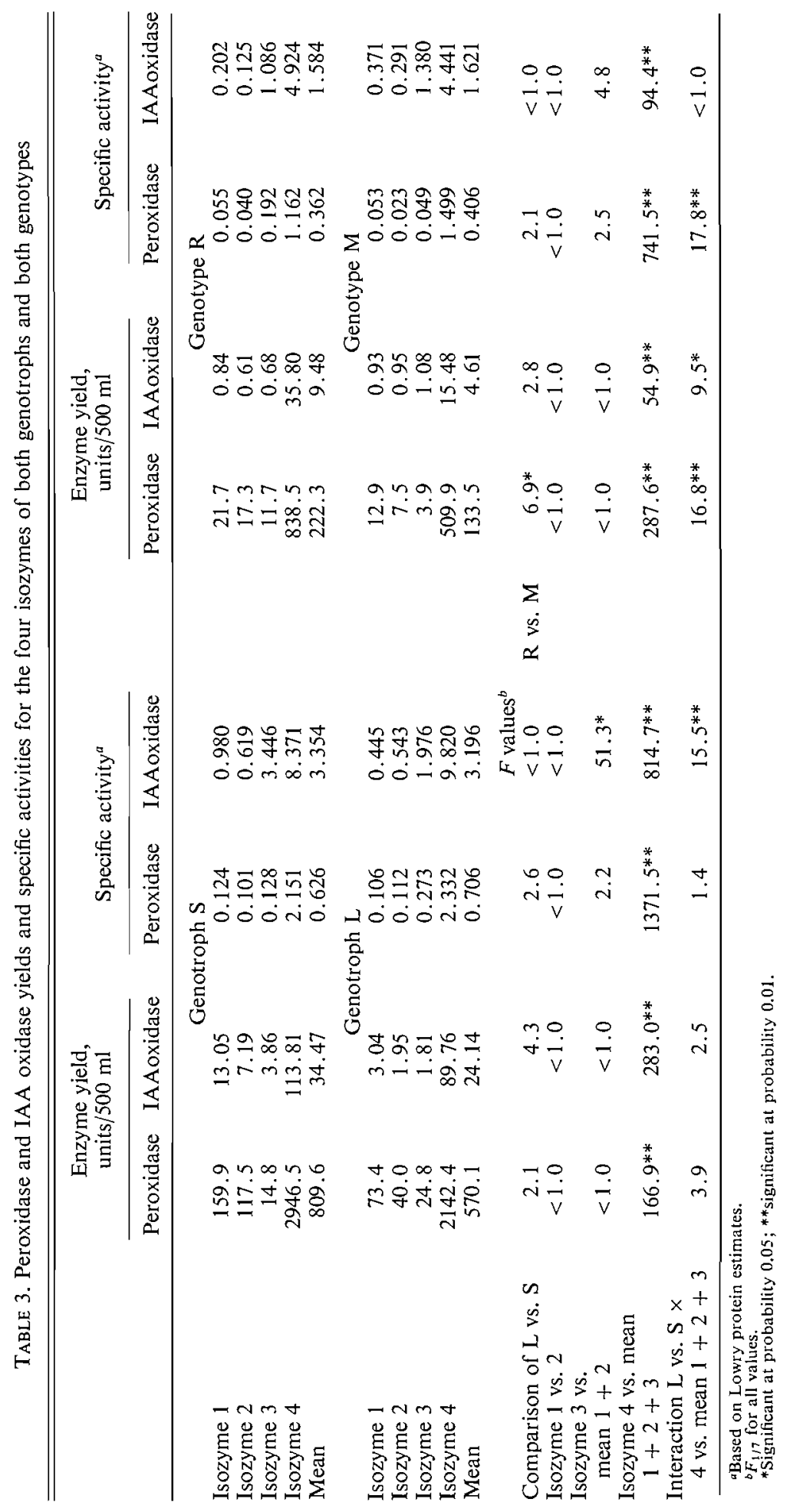


TABLE 4. Peroxidase : IAA oxidase correlation coefficients, slopes of regression, and adjusted IAA oxidase yield means for genotrophs and genotypes

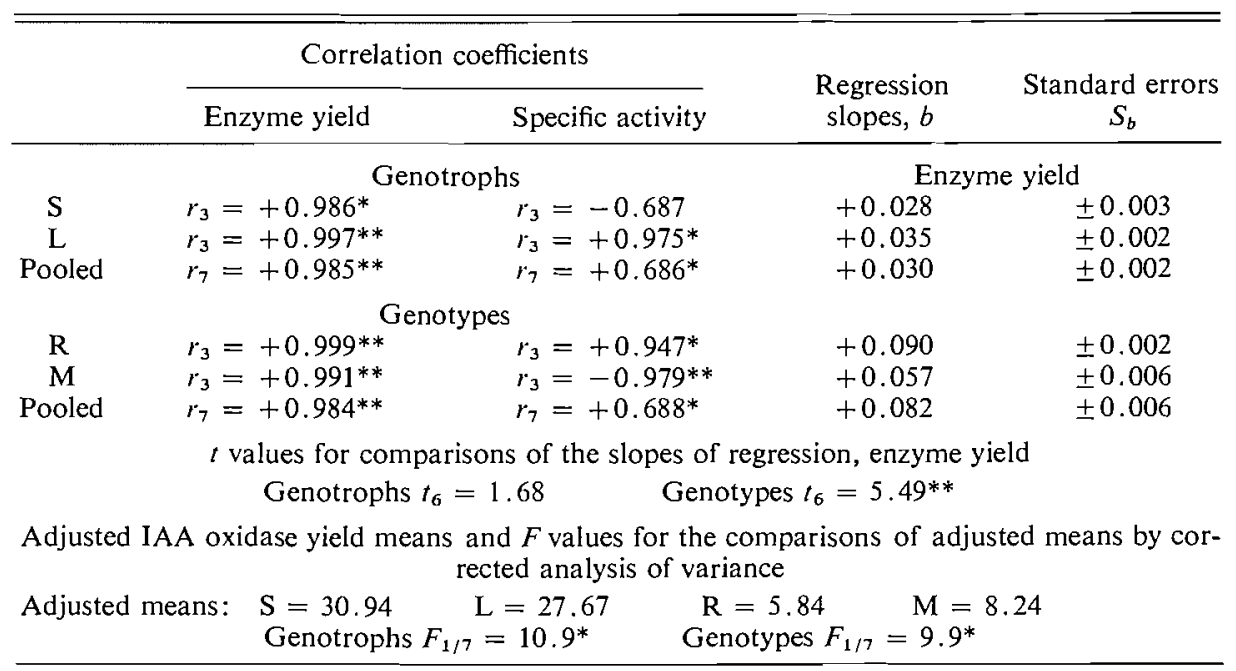

*Significant at probability $0.05 ; * *$ significant at probability 0.01 .

TABLE 5. Mean molecular weight estimates for the four isozymes of both genotrophs and both genotypes

\begin{tabular}{|c|c|c|c|c|c|}
\hline & \multicolumn{2}{|r|}{ SDS } & \multicolumn{2}{|c|}{ Gel filtration } & \\
\hline & & \multicolumn{2}{|c|}{ Genotroph S } & \multicolumn{2}{|l|}{ Genotype R } \\
\hline & Isozyme 1 & 44710 & 42800 & 41300 & \\
\hline & Isozyme 2 & 48895 & 44000 & 43000 & \\
\hline & Isozyme 3 & 88940 & 61300 & 60300 & \\
\hline & Isozyme 4 & 41355 & 43800 & 43600 & \\
\hline & Mean & 56960 & 47975 & 47050 & \\
\hline & & \multicolumn{2}{|c|}{ Genotroph L } & \multicolumn{2}{|l|}{ Genotype M } \\
\hline & Isozyme 1 & 46710 & 40200 & 38300 & \\
\hline & Isozyme 2 & 46935 & 42200 & 41800 & \\
\hline & Isozyme 3 & 87410 & 60200 & 57700 & \\
\hline & Isozyme 4 & 40005 & 41500 & 42000 & \\
\hline & Mean & 55265 & 46025 & 44950 & \\
\hline \multicolumn{6}{|c|}{$F$ values $^{a}$} \\
\hline & & & & $\begin{array}{l}\text { Combined analysis } \\
\text { L vs. S }\end{array}$ & $\begin{array}{r}F \text { values }^{b} \\
11.2^{* *}\end{array}$ \\
\hline Comparison of $\mathrm{L}$ vs, $\mathrm{S}$ & 1.5 & $8.5^{*}$ & $14.3 * *$ & R vs. M & $13.3 * *$ \\
\hline Isozymes & & & & $L+S$ vs. $R+M$ & $6.1^{*}$ \\
\hline 1 vs. 2 & 1.0 & 3.3 & $13.7^{* *}$ & 2 vs. 4 & 1.0 \\
\hline 4 vs. mean $1+2$ & $17.1^{* *}$ & 1.0 & $7.9 *$ & 1 vs. $2+4$ & $17.8 * *$ \\
\hline 3 vs. mean $1+2+4$ & $695.7 * *$ & $436.4^{* *}$ & $611.8^{* *}$ & 3 vs. $1+2+4$ & $1456.2 * *$ \\
\hline
\end{tabular}

for genotypes. The molecular weight of isozymes 2 and 4 were not significantly different, the molecular weight of isozyme 1 was significantly lower than the mean of 2 and 4 , and the molecular weight of isozyme 3 was significantly higher than the mean of the other three isozymes.
In the SDS data for genotrophs, the molecular weight of isozyme 3 was also significantly higher than the mean of the other three isozymes. However, the SDS molecular weights showed no difference in the molecular weights of isozymes 1 and 2, and the molecular weight of isozyme 4 
was significantly lower than the mean of 1 and 2 . Further, the molecular weight estimates for isozyme 3 were substantially higher by this method than by gel filtration. The mean molecular weight of $\mathrm{S}$ was higher than that of $\mathrm{L}$, but the genotroph difference was not significant. The variability in the molecular weight estimates of isozyme 3 was high compared with that of the other three isozymes. When the SDS data were reanalysed omitting isozyme 3 , the genotroph difference was significant $\left(F_{1,5}=11.0\right)$. The high molecular weight estimates obtained for isozyme 3 , by the SDS method compared to gel filtration, could not, however, be attributed to the high variability.

\section{Discussion}

Despite the disadvantages associated with the Lowry method of protein estination (Eastoe 1972), the Lowry protein values were used to calculate percentage $\mathrm{CHO}$ and specific activities because $(a)$ no protein estimates were obtained for isozyme 3 , the isozyme with lowest yield, by the Waddell method and $(b)$ it was felt that the low protein yield values obtained by the Coomassie method resulted from reduced sensitivity of the glycoproteins to Coomassie stain (for example, similar reduced sensitivity of glycoproteins might account for the results obtained by Gibbons (1972) and by Fazekas de St. Groth et al. (1963)). In choosing between the two methods of CHO estimation, the PAS method would be preferred because of known possible complications with the B-T method (Badin et al. 1953).

Relative estimates of a given characteristic, for particular enzyme variants, obtained from different assay methods can, however, give indications of structural differences between variants. For example, the Lowry protein yields of isozymes 1 and 4 were similar but the Coomassie protein yield of isozyme 4 was higher than that of isozyme I, suggesting that isozyme 4 was relatively more sensitive to Coomassie stain and therefore possibly contained a lower percentage $\mathrm{CHO}$ than isozyme 1 . This indication was substantiated by the $\mathrm{CHO}$ yield and percentage $\mathrm{CHO}$ values of these two isozymes. Further, the observed increased specific activities of isozyme 4 , over 1 , could stem from this percentage $\mathrm{CHO}$ difference. Higher molecular weight for 1 , compared to 4 , observed for genotrophs by SDS electrophoresis, would be consistent with the indicated percentage $\mathrm{CHO}$ difference; although by gel filtration the molecular weight of 1 and 4 were reversed. Glycoproteins show anomalous behaviour both on gel filtration and on SDS electrophoresis. However, on gel filtration this behaviour need not depend on percentage $\mathrm{CHO}$ but can depend on the extent to which the $\mathrm{CHO}$ alters the shape of the molecule (Andrews 1965). Using SDS electrophoresis the anomalous behaviour (dependent on percentage $\mathrm{CHO}$ ) is thought to be minimized in gels containing $10 \%$ or higher polyacrylamide (Segrest 1971). The differing relationship between the apparent molecular weights of isozymes 1 and 4 could, therefore, again be attributed to structural differences between these isozymes. The differences between isozymes 1 and 4, their high percentage purities, and their high protein yields recommend them, in preference to isozymes 2 and 3, for further experimentation.

The genotroph difference in peroxidase yield, rather than in specific activity, indicated that $S$ synthesized more peroxidase per unit weight of main stem than L. Similarly for genotypes, R synthesized more peroxidase than M. Genotroph molecular weight differences were consistent with observed $R m$ differences; higher molecular weight resulting in lower $R m$ for each isozyme of S, compared with the corresponding isozyme of L. For corresponding genotype isozymes, $\mathrm{Rm}$ was lower for R than M (Fieldes et al. 1976) and again the apparent molecular weight values were higher for $\mathrm{R}$ than for $\mathrm{M}$. There was no indication, however, that molecular weight differences between corresponding genotroph isozymes resulted from increased percentage $\mathrm{CHO}$ in $\mathrm{S}$ over $\mathrm{L}$.

The demonstration here that four isolated enzyme variants, from two flax genotrophs and two flax genotypes, exhibited both peroxidase and IAA oxidase activity supports the contention that these dual enzyme functions reside on the one molecule (Hoyle 1965). In terms of auxin destruction, the reduced percentage of basal branching observed in $\mathrm{S}$ and $\mathrm{M}$, compared with $\mathrm{L}$ and $\mathrm{R}$ respectively, might have indicated lower levels of IAA oxidase activity in S and M (Thimann 1972). Enzyme yield was in fact lower for $M$ than for R, but was higher for $S$ than for $L$. Further, although similarities between $S$ and $M$, compared with $L$ and $R$, were detected in the balance between peroxidase and IAA oxidase activities, the IAA oxidase activity of a constant 
amount of peroxidase was apparently higher for $S$ and $M$ than for $L$ and $R$ respectively. The physiological significance of the relative IAA oxidase activities between genotrophs and between genotypes, therefore, remains unclear.

\section{Acknowledgment}

The work was supported by a grant from the National Research Council of Canada, to whom thanks are extended.

ANDREWS, P. 1965. The gel-filtration behavior of proteins related to their molecular weights over a wide range. Biochem. J. 96: 595-606.

BADIN, J., C. JACKSON, and M. Schubert, 1953. Improved method for determination of plasma polysaccharides with tryptophan. Proc. Soc. Exp. Biol. Med. 84: 288-291.

DARBYSHIRE, B. 1973. The glycoprotein nature of indoleacetic acid oxidase/peroxidase fractions and their development in pea roots. Physiol. Plant. 29: 293-297.

DURRANT, A. 1962 $a$. Induction, reversion and epitrophism of flax genotrophs. Nature, 196: 1302-1304.

$1962 b$. The environmental induction of heritable change in Linum. Heredity, 17: 27-61.

1971. Induction and growth of flax genotrophs. Heredity, 27: 277-298.

EASTOE, J. E. 1972. Amino acid analysis of glycoproteins. In Glycoproteins. Vol. 5. Edited by A. Gottschalk. Elsevier Publishing Co., New York. pp. 158-207.

Fazekas de St. Groth, S., R. G. Webster, and A. DATYNES. 1963. Two new staining procedures for quantitative estimation of proteins on electrophoretic strips. Biochim. Biophys. Acta, 71: 377-391.

Fieldes, M. A., N. Bashour, C. L. Deal, and H. TYSON. 1976. Isolation of peroxidase isozymes from two flax genotypes by column chromatography. Can. J. Bot. 54: $1180-1188$

Fieldes, M. A., and H. TYSON. 1972. Activity and relative mobility of peroxidase isoenzymes in genotrophs and genotypes of flax (Linum usitatissimum L.). Can. J. Genet. Cytol. 14: 625-636.

1973a. Activity and relative mobility of peroxidase and esterase isozymes of flax (Linum usitatissimum) genotrophs. I. Developing main stems. Can. J. Genet. Cytol. 15: 731-744.

$1973 \mathrm{~b}$. Activity and relative mobility of peroxidase and esterase isozymes of flax (Linum usitatissimum) genetrophs. II. $F_{1}$ hybrids and nuclear DNA reversion types. Can. J. Genet. Cytol. 15: 745-755.

Galston, A. W., J. Bonner, and R. S. Baker. 1953. Flavoprotein and peroxidase as components of the in- dole acetic acid oxidase system of peas. Arch. Biochem. Biophys. 42: 456-470.

Gibions, R. A. 1972. Physico-chemical methods for the determination of the purity, molecular size and shape of glycoproteins. In Glycoproteins. Vol. 5. Edited by A. Gottschalk. Elsevier Publishing Co., New York. pp. 31-140.

Gordon, S. A., and R. P. Weber. 1951. Colorimetric estimation of indoleacetic acid. Plant Physiol. 26: 192-195.

HART, M. A., H. Tyson, and R. Bloomberg. 1971. Measurement of activity of peroxidase isoenzymes in flax (Linum usitatissimum). Can. J. Bot. 49: 2129-2137.

Hess, D. 1968. Biochemische Genetik. Springer-Verlag, Berlin.

HOYLE, M. C. 1972. Indoleacetic acid oxidase: a dual catalytic enzyme? Plant Physiol. 50: 15-18.

LAEMMLI, U. K. 1970. Cleavage of structural proteins during the assembly of the head of bacteriophage $T_{4}$. Nature, 227: 680-685.

Lowry, O. H., N. J. Rosenbrough, A. L. FARr, and R. L. Randall. 1951. Protein measurements with the Folin phenol reagent. J. Biol. Chem. 193: 265-275.

Maehly, A. C., and B. Chance. 1954. Methods of biochemical analysis. Vol. I. Interscience Publications, New York. pp. 358-424.

SEGREST, J. P., R. L. Jackson, E. P. AndREws, and V. T. MARCHeSI. 1971. Human erythrocyte membrane glycoprotein: a re-evaluation of the molecular weight as determined by SDS polyacrylamide gel electrophoresis. Biochem. Biophys. Res. Commun. 44: 390-395.

Shannon, L. M., E. Kay, and J. Y. Lew. 1966. Peroxidase isozymes from horseradish roots. I. Isolation and physical properties. J. Biol. Chem. 241: 2166-2172.

Th1mann, K. V. 1972. The natural plant hormones. In Plant physiology. Vol. VIB. Edited by F. S. Steward. Academic Press, New York. pp. 3-332.

WADDELL, W. J. 1956. A simple ultraviolet spectrophotometric method for the determination of protein. J. Lab. Clin. Med. 48: 311-314.

WEBER, K., and M. OsBorN. 1969. The reliability of molecular weight determinations by dodecyl sulfatepolyacrylamide gel electrophoresis. J. Biol. Chem. 244: 4406-4412.

Weber, K., J. R. Pringle, and M. Osborn. 1972. Measurement of molecular weights by electrophoresis on SDS-acrylamide gel. In Methods in enzymology. VoI. 26. Edited by C. H. W. Hirs and S. N. Timasheff. Academic Press, New York. pp. 3-51.

Wishart, J. 1950. Field trials. II. The analysis of covariance. Commonw. Bur. Plant Breed. Genet. Tech. Commun. No. 15.

Zacharius, R. M., T. E. Zell, J. H. Morrison, and J. J. WOODLOCK. 1969. Glycoprotein staining following electrophoresis on acrylamide gels. Anal. Biochem. 30: $148-152$. 